\title{
UNERGATIVE ADJECTIVES AND PSYCH VERBS
}

\section{Hans Bennis}

\section{$1 \quad$ Introduction 1}

The idea that the verb phrase is a layered constituent has been around in the literature for some time, e.g. Larson 1988, Hale \& Keyser 1993. In the minimalist program, as sketched in Chomsky 1995, 2001, shell theory plays an important role as well. In this paper I will argue that a particular interpretation of shell theory may provide insight into long standing problems such as the nature of syntactic ergativity and the structure of psychological verbs. Let us consider a VP-structure with a V-type shell (the $v \mathrm{P}$ ) on top of it. Given binary branching this structure is able to accomodate three argument phrases, in resp. the complement of $\mathrm{V}$, the specifier of $\mathrm{V}$, and the specifier of $v$. In Chomsky's words:

The internal arguments occupy the positions of specifier and complement of V. Accordingly, the external argument cannot be lower than [Spec, v]. If it is [Spec, $v$ ], as I will assume, then the $v-\mathrm{VP}$ configuration can be taken to express the causative or agentive role of the external argument. It would be natural to extend the same reasoning to transitive verb constructions generally, assigning them a double-VP structure as in (115) [=(1) H.B.], the agent role being understood as the interpretation assigned to the $v-\mathrm{VP}$ configuration. A V-object construction is therefore maximal, not $V^{\prime}$. [...] If intransitive (unergative) verbs are hidden transitives, as Hale and Keyser suggest, then only unaccusatives lacking agents would be simple VP structures.

Chomsky 1995 (p.315/316)

$v \mathrm{P}$

Spec $\quad v^{\prime}$

$v \quad \mathrm{VP}$

Spec $\quad V^{\prime}$

V Compl

1 I would like to thank Sjef Barbiers, Marcel den Dikken and the editors of this volume for their comments on an earlier version of this paper. It has been presented in Berlin (1998) and Leiden (1998). I thank the audiences for their remarks. 
Chomsky's position has several interesting implications. First of all, it is argued that the nature of thematic roles is essentially configurational, i.e. the presence of small $v$ expresses the interpretative concept of agentivity or causativity, which in turn requires the specifier of $v$ to be interpreted as a position for the argument bearing the thematic role of Agent or Cause (cf. Kratzer 1996). In this perception the lexicon does not have to specify the presence or the nature of the external argument. An indication whether $v$ should be added to the V-projection is sufficient. Since the meaning of a lexical verb might be decomposed into an activity/causativity part and a core verbal part we may eliminate the external argument from the lexical representation altogether. To some extent this is the approach adopted by Hale \& Keyser, although the their actual execution of this idea differs rather substantially.

A similar consequence is that unaccusativity is structurally expressed; not by the lack of an underlying external argument, but rather by the absence of the $v$-projection. Again, this might be the result of the lack of agentivity/causativity in the meaning of the verb, in which case unaccusative verbs do not have to be listed in the lexicon as such.

\section{The Burzio generalization}

This perspective on unaccusativity - unaccusative projections are VPs, unergative projections are $\nu \mathrm{Ps}-$ gives rise to a change in perspective on the presence of arguments. As will be clear, the presence of an external argument depends on the presence of a small $v$, and vice versa; or in Chomsky's words: "The external role is a property of the $v$-VP configuration, and a specifier bearing this role is therefore a necessary part of the configuration; a transitive (or rather: unergative; H.B.) verb assigns an external role by definition." (Chomsky 1995, p. 316).

The proposal above relates the presence of $v \mathrm{P}$ to the interpretive property of agentivity/ causativity. Absence of a small $v$ gives rise to unaccusativity. However, there are non-agentive, unergative constructions, in particular stative ones. If we want to capture the distinction unergative - unaccusative in structural terms $-v \mathrm{P}$ vs. VP - we should not assimilate the $v$-projection with one particular meaning type. Small $v$ can be either dynamic or stative (cf. Kratzer 1994). In a sentence such as (2a) the external argument is interpreted as an Agent as the consequence of $v$ being dynamic; in (2b) the external argument is interpreted as Possessor $^{2}$, due

2 The thematic role Possessor indicates that the argument possesses the state denoted by the VP. 
to the fact that $v$ is stative, whereas the structure in $(2 \mathrm{c})$ is unaccusative given the lack of a $v$-projection.

(2) a John greets the audience.

b John knows the audience.

c John dies.

This brings us to the generalization in (3).
If $v$ is dynamic :
$[$ Spec, $v]$ is Agent
(John greets the audience)
If $v$ is stative $\quad: \quad[$ Spec, $v]$ is Possessor
(John knows the audience)

From this perspective we may easily capture the Burzio generalization - lack of external argument : lack of accusative Case - in structural terms. ${ }^{3}$ In order to do so we need to give the $v$-projection a role not only in the presence of an external argument, but also in the assignment of accusative Case. The ingredients for the latter role of the small $v$ are also present in the Minimalist Program. After a decade of Agr-projections, Chomsky tries to eliminate Agr as a separate functional projection (Chomsky 1995:4.10).

The obvious problem for a theory in which formal relations or checking relations are relations between a head and its specifier is the question how to assign accusative Case to the object. The main reason for the introduction of AgrO was to create a spec-position in which it is possible to assign Case to the object. In order to get rid of AgrO, Chomsky argues that a phrase may have multiple specifiers. When we adjoin the object to XP, a second specifier position is created that may be involved in Case assignment. If we take $v$ to be a head that is able to assign accusative Case, and if an object can be assigned Case by being adjoined to $v \mathrm{P}$, we no longer need AgrO for Case assignment.

We are now in a position to account for the Burzio generalization in structural terms. If it is indeed $v$, and not $\mathrm{V}$, that is able to assign accusative Case, the absence of $v$ has two consequences: there is no external argument and no accusative Case. It leads to the conclusion

3 Other attempts to derive the Burzio generalization can be found in Reuland (2000). 
that the two implications below are both valid, since the presence of an external argument and the availability of accusative Case crucially depend on the presence of $v$ :

a) if there is no external argument, no (structural) accusative Case can be assigned;

b) if no (structural) accusative Case is available, no external argument can be generated. One related question should be raised in connection with this multiple specifier approach. If the external argument is generated by Merge in the specifier postion of $v$, and the internal argument can be raised/adjoined to $v \mathrm{P}$ (the outer spec position) in order to check its objective Case feature, why can't the external argument, which is also present in [Spec,v] (the inner spec position), check the objective Case feature of $v$. If that would be the case, we incorrectly predict internal arguments to become subjects (raising to $[\mathrm{Spec}, \mathrm{T}]$ ) and external arguments to show up as objects. Of course, this is a general question to the multiple specifier approach. Chomsky argues that "Subj inserted by Merge in [Spec, $v]$ is not in the checking domain of $v$, because it does not head a nontrivial chain." (Chomsky 1995:352). ${ }^{4}$ Chomsky's approach rather crucially separates theta-positions from Case-positions, or rather theta-checking from Case-checking, in terms of his Chain Condition: "an argument is a non-trivial chain $\mathrm{CH}=(, t)$, where $\_$has raised for feature checking and $t$ is in a _-position" (Chomsky 1995:312). Let us assume that the complementarity of theta-checking and Case-checking is a general property of the theory. It then follows that only raised arguments can check the Case feature of $v$. This gives us the results we want: [Spec,v] is a position in which both theta-checking and Case-checking may apply, but only with respect to different arguments. The argument that checks its theta-feature in [Spec,v] gets interpreted as the agent, the causer or the possessor argument. This argument has to move to a higher projection in order to check its Case feature. The argument that checks its Case feature in $[\mathrm{Spec}, v]$ is the argument with objective Case; this argument must have been moved from a theta-position lower in the structure in order to establish a non-trivial chain.

Adopting the multiple specifier approach we provide a simple explanation of the Burzio generalization. This part of the theory now contains the following three ingredients:
A an external argument is present iff a $v$-projection is added to VP;
B accusative Case can be checked in $[$ Spec, $v]$ only;
$\mathrm{C}$ only internal arguments may check the Case-assigning feature that is intrinsic to $v$.

4 Chomsky extensively argues that adjunction of the subject to its own projection, creating an outer spec position, is not an available option either. This implies that the subject has to move out to check its Case feature. 
Together these ingredients make the Burzio generalization follow from the theory and we can get rid of this unidentified theoretical object.

However, as I will demonstrate in the following sections, this perspective is too simple. I will extensively show that the Burzio generalization is partially wrong. I'll argue against the idea that the presence of a small $v$ is necessarily connected to the presence of an external argument (see A above). To be more precise, only one of the implications (A1) is valid. The implication A2 appears to be incorrect.

A1 if an external argument is present, $v$ has been generated;

A2 if $v$ is generated, an external argument has to be present.

If $\mathrm{A} 2$ is not correct, the theory will predict the occurrence of $v \mathrm{P}$ without external argument. This approach will thus give us three distinct configurations:

i) VP without a $v$-projection;

ii) a $v$-projection without an external argument;

iii) a $v$-projection with an external argument.

The external argument can be absent due to the absence of $v \mathrm{P}(\mathrm{i})$ or to the absence of _-assigning properties intrinsic to $v$ (ii). We thus distinguish two different types of ergativity: simplex ergativity (i) and complex ergativity (ii). 5 We will see that (i) and (ii) differ in various ways.

In order to substantiate this proposal empirically, I will first concentrate on adjectival constructions in Dutch. It will be shown that three different adjectival construction types have to be distinguished structurally. In order to do so, I'll introduce the concept of small $a$. The three different construction types correspond to (i)-(iii) above: AP, $a \mathrm{P}$ without EA, and $a \mathrm{P}$ with EA. After having established the three way system for adjectival phrases, we will concentrate on present participles. These participles are somewhere in between verbs and adjectives. Particularly interesting are present participles of psychological verbs. Especially the occurrence of the experiencer argument is significant. If the present participle construction is internally verbal the experiencer argument may be realized, whereas the occurrence of an experiencer leads to ungrammaticality in adjectival present participle constructions. From this we conclude that the

The idea that unaccusatives can be either simplex or complex is also proposed, in a different context, in Alexiadou \& Anagnostopoulou (this volume). They appeal to the relative complexity of structure in order to accommodate the systematic presence or absence of morphology associated with detransitivization in different classes of unaccusatives in Greek. 
experiencer is structurally Case-marked, which in turn leads to the conclusion that psychological verb constructions of the relevant type (the preoccupare class; cf. Belletti \& Rizzi 1988) are to be analysed as $v \mathrm{P}$. The next step in the argumention involves the argument that the relevant class of psychological verbs is ergative in the thematic sense, i.e. no external argument has been generated. If correct, we have shown the existence of verbal constructions of type (ii). It now follows that the three different types of psychological verbs correspond to the three different construction types distinguished above: the temere-class is argued to be a regular transitive construction of type (iii), the preoccupare-class is of type (ii), and the piacere-class behaves like the simplex ergatives of type (i).

The final conclusion of this article is that the Burzio generalization should not have any theoretical status. It is partially wrong, and, in as far as it is correct, the consequences follow from the theory without additional stipulation. Moreover, it is argued that unaccusativity is theoretically a meaningless concept. The crucial properties with respect to the presence and absence of arguments and their configurational properties are indirectly related to Case theory only. The most important distinction that is introduced in this paper is the distinction between simplex ergativity and complex ergativity. ${ }^{6}{ }^{7}$

\section{$3 \quad$ Simple ergative adjectives}

Cinque $(1989,1990)$ has argued that the class of adjectives should be divided into ergative and non-ergative adjectives. He discusses a number of criteria which provide substance to a

6 In this paper I use the term 'ergativity' (in the spirit of Burzio 1986) for what other people in this volume use the term 'unaccusativity'. The reason is that an important part of the discussion focusses on adjectives. Since adjectives do not assign structural accusative Case in general, the term 'unaccusative adjective' seems irrelevant, in contrast to the term 'ergative adjective'. The crucial point is that the distinction ergative - unergative refers to a thematic distinction, rather than a Case distinction.

7 Some articles in this volume, notably Borer (this volume) and Van Hout (this volume), take unaccusativity to depend on telecity, and do not address the presence or absence of the external argument as a crucial property of ergative constructions. These proposals agree with the account presented here that unaccusativity is mainly a syntactic phenomenon that is not determined by properties of the verb in the lexicon. Other papers, notably Alexiadou \& Anagnostopoulou (this volume) and Embick (this volume), take the external argument property to be central and do not address the notion of telicity. It is not so clear to me how telicity could be taken to be the relevant notion in the case of the stative unaccusatives that are presented in this paper. 
distinction along these lines for Italian and German. Below I will discuss three phenomena that show that a division into ergative and unergative adjectives is motivated for Dutch as well (for a more extensive motivation of this distinction in Dutch cf. Bennis 2000). It is evident that unaccusativity is irrelevant here, given that adjectives do not assign structural Case. In order to develop a division into ergative and non-ergative adjectives, we have to rely on different criteria to show that (4a) and (4b) differ with respect to ergativity (4a is ergative; $4 \mathrm{~b}$ is unergative).

(4) a Deze mensen zijn mij bekend.

these people are me known

b Deze mensen zijn mij trouw.

these people are me loyal

\subsection{Inversion}

In Dutch inversion of subject and object is highly restricted. If we do not take into account wh-movement - i.e. movement to $[\mathrm{Spec}, \mathrm{C}]$ as in question formation, topicalization, and relativization - the subject generally precedes the (in)direct object. There is however one class of exeptions: when the subject is an underlying direct object, as in the case of passives and ergatives, the indirect object may precede the subject. The topic of argument inversion in Dutch has been amply discussed in the literature (a.o. Den Besten 1982, Everaert 1982, Hoekstra 1984, Bennis 1986). In (5a) we see that the order IO-SUBJ leads to ungrammaticality in ditransitive sentences. In $(5 b, c)$ we observe that the order IO-SUBJ is possible in passive and ergative clauses. ${ }^{8}$

(5) a dat DIE JONGEN HEM / *HEM DIE JONGEN beloofde naar huis te gaan that that boy ${ }_{\mathrm{DO}} \mathrm{him}_{\mathrm{IO}} / \mathrm{him}_{\mathrm{IO}}$ that boy

b dat DIE JONGEN HEM / HEM DIE JONGEN werd voorgesteld that that boy $\operatorname{Dim}_{\mathrm{IO}} / \operatorname{him}_{\mathrm{IO}}$ that boy $\mathrm{DO}_{\mathrm{DO}}$ was introduced

c dat DIE JONGEN HEM / HEM DIE JONGEN opviel that that boy $_{\mathrm{DO}} \operatorname{him}_{\mathrm{IO}} / \mathrm{him}_{\mathrm{IO}}$ that boy DO $_{\text {struck }}$

8 In the examples in (5-7) the indirect object is a pronoun. Inversion is possible with full DPs as well. 
Given that adjectives in Dutch may occur with indirect objects, we have the opportunity to check whether a superficial subject is derived by movement from object position or not. If inversion is available, the subject has been moved, just as in $(5 b, c)$. It is indeed the case that the class of adjectives that have indirect objects can be divided into adjectives that allow inversion, and adjectives that don't. This can be observed in (6) and (7).

(6) a dat DAT PROBLEEM HEM / HEM DAT PROBLEEM duidelijk is that that problem $_{\mathrm{DO}} \mathrm{him}_{\mathrm{IO}} / \mathrm{him}_{\mathrm{IO}}$ that problem $\mathrm{DO}$ clear is

b dat DIE JONGEN HEM / HEM DIE JONGEN bekend is that that boy $_{\mathrm{DO}} \operatorname{him}_{\mathrm{IO}} / \mathrm{him}_{\mathrm{IO}}$ that boy $\mathrm{y}_{\mathrm{DO}}$ well-known is dat DIE JONGEN HEM / *HEM DIE JONGEN trouw / gehoorzaam is that that boy $_{\mathrm{DO}} \operatorname{him}_{\mathrm{IO}} / \mathrm{him}_{\mathrm{IO}}$ that boy $\mathrm{D}_{\mathrm{DO}}$ loyal / obedient is

We thus observe that the class of adjectives can be divided into adjectives that pattern with ergative verbs (duidelijk 'clear', bekend 'well-known'), and adjectives that behave like unergatives (trouw 'loyal', gehoorzaam 'obedient').

\section{2 $A S$-clauses}

The second criterium, which is also applicable in German and Italian, concerns the occurrence of adjectives in so-called as-clauses (cf. Stowell 1987, Cinque 1989). As has been demonstrated by Stowell, the gap in as-clauses always corresponds to an underlying sentential object. Simple examples of this can be found in (8). In (8a) the gap is in object position, whereas in (8b) the gap corresponds to the subject/object of a passive and in (8c) to the subject/object of an ergative verb. The non-occurrence of subject gaps is demonstrated in (9).

(8) a Zoals ik zei $e$, houdt Jan van slakken. as I said, John likes snails

b Zoals $e$ door iedereen beweerd wordt, houdt Jan van slakken. as by everybody is said, John likes snails

c Zoals $e$ mij opgevallen is, houdt Jan van slakken. as me struck is, John likes snails 
(9) a *Zoals $e$ zijn onschuld bewijst, had Jan geen slakken gegeten. as proves his innocence, John had not eaten snails

b *Zoals $e$ mij van zijn gelijk overtuigt, lust Jan geen slakken. as me of his right convinces, John doesn't like snails

The same division we encounter in the case of adjectives. Some adjectives appear in the as-construction, whereas other adjectives do not. This difference can be explained if we assume that the adjectives in (10) may select a sentential object, contrary to the adjectives in (11).

(10) a Zoals $e$ mij duidelijk werd, houdt Jan niet van slakken. as me clear became, John doesn't like snails

b Zoals $e$ bekend is, houdt Jan niet van slakken. as is well-known, John doesn't like snails

(11) a *Zoals $e$ grappig is, houdt Jan van slakken. as is funny, John likes snails

b *Zoals $e$ verrassend is, houdt Jan van slakken. as is surprising, John likes snails

If it is the correct conclusion that the empty element in (10) is in object position - i.e. the thematic position for the sentential argument is the object position of the adjective - it follows that the surface subject of the same two adjectives in (12) is moved from object to subject position, thus giving rise to an ergative analysis.

(12) a Jans afkeer van slakken is duidelijk.

Johns revulsion at snails is clear

b Jans afkeer van slakken is mij bekend.

Johns revulsion at snails is me well-known

This test indicates that adjectives of the type duidelijk 'clear', bekend 'well-known', zeker 'certain' and waarschijnlijk 'probable' are ergative in their thematic organization. 


\subsection{Complementizer selection}

A third criterion to distinguish ergative adjectives from unergative ones is the possibility to select the complementizer of a related argument clause. It is well-known that the form of the complementizer of a finite sentential complement (that or whether) depends on properties of the matrix verb. This selection property only shows up when the sentential argument is the object of the verb. Sentential subjects or adjuncts do not show this phenomenon. In the case of clauses selected by an adjectival head we observe that variability in complementizer selection shows up with adjectives such as duidelijk 'clear' and bekend 'well-known', but not with adjectives such as acceptabel 'acceptable' and plezierig 'pleasant'. A negative context generally supports the selection of the complementizer of 'whether' in complement clauses. We observe that on-prefixation cooccurs with of-selection in the case of adjectives of the duidelijk-class only.

(13) a Het is ON-duidelijk / ON-bekend DAT / OF Jan naar huis gegaan is. it is unclear / unknown that / whether John is gone home

b Het is ON-acceptabel / ON-plezierig DAT / * OF Jan naar huis gegaan is. it is unacceptable / unpleasant that / whether John is gone home

The examples in (13) again show that the (clausal) argument of the adjective in (13a) is the thematic object of the adjective, whereas the clausal argument in (13b) is not an object.

\subsection{The $a$-shell}

The arguments given above suffice to show that the distinction ergative - unergative is motivated in the adjectival domain. The question now arises how we can account for this distinction in structural terms. In section 1 , it was demonstrated that in minimalist terms verbal ergativity may be structurally expressed by the absence of a $v$-shell. The occurrence of an external argument forces the presence of a $v$-shell in unergatives. The same type of reasoning is applicable to adjectival projections. Ergative adjectives such as duidelijk 'clear' and bekend 'well-known' can be analysed as bare APs. The indirect object is generated in [Spec,A], whereas the object/ subject of the adjectives is generated as the complement of A. Unergative adjectives such as trouw 'loyal' and gehoorzaam 'obedient' show up with an external argument. The indirect object is again generated in $[\mathrm{Spec}, \mathrm{A}]$. To create a structural difference between ergative and unergative 
projection, we need to create another layer of structure. If we adopt structural parallellism between $\mathrm{A}-$ and $\mathrm{V}$-projections, the consequence is that unergative adjectives require an adjectival shell on top of the bare AP. Small $a$ in adjectival projections is fully symmetrical to small $v$ in verbal projections. The two structures are presented in (14).

AP

Spec

mij
$\mathrm{A}^{\prime}$

Compl deze mensen b

$a \mathrm{P}$

Spec

$a^{\prime}$

deze mensen
A

bekend a

AP

Spec

mij
A

trouw

In both (14a) and (14b) the indirect object mij appears to be inherently Case-marked. In (14a) the object of bekend moves to a higher projection (TP) in order to receive Case. In (14b) the external argument deze mensen moves to TP for Case reasons as well. Although the superficial strings of these constructions are similar, as in (4), we have seen that there are good arguments to suppose that the underlying structures are substantially different. Additional corroboration for a difference in underlying structure concerns the semantic relation between the adjective and the DP deze mensen in (4). In (4b/14b) the DP deze mensen receives an interpretation that is similar to the 'possessive' interpretation of the subject of stative verbs, cf. $(2 \mathrm{~b} / 3)$. This interpretation is not available in (4a/14a). In line with the view that there exists a direct relation between syntactic structure and thematic organization, we assign small $a$ an interpretation that is comparable to the interpretation of (stative) small $v$.

The $a$-shell in (14b) differs in two respects from the $v$-shell in unergative verbal projections. First, small $a$ is not able to assign Case. This implies that adjunction to $a \mathrm{P}$ does not create an outer specifier position in which Case features can be checked. An internal argument has to be moved to a position higher than $[\mathrm{Spec}, a]$ in order to receive Case. A second difference 
between $a$ and $v$ is that the aspectual interpretation of the small head appears to be constant in the case of adjectives. All adjectival projections are stative, whereas verbal projection are sometimes stative, sometimes dynamic.

\section{Complex ergative adjectives}

Within the class of unergative adjectives a systematic division in two groups is called for. In this section it is demonstrated that constructions of the type in (15a) have to be structurally distinguished from constructions of the type in (15b).

(15) a Jan is trouw / gehoorzaam.
John is loyal / obedient
b Dat is trouw / gehoorzaam.
that is loyal / obedient

Below I'll provide three arguments to show that a structural distinction between (15a) and (15b) is warranted. For more argumentation on this issue I refer to Bennis (2000).

\subsection{Indirect objects}

The construction of the type in (15a) - type A - may involve the realization of an indirect object with adjectives such as trouw 'loyal' and gehoorzaam 'obedient'. Interestingly, the same indirect object is required to be absent if the adjectival subject does not refer to the person who possesses the adjectival property (Jan in (16a)), but rather to the theme that expresses the adjectival property (dat in (16b)) — type B.

(16) a

Jan is mij trouw / gehoorzaam.

[type A]

John is me loyal / obedient

b Dat is $(*$ mij) trouw / gehoorzaam.

[type B]

that is (me) loyal / obedient

There is no interpretive reason to expect this difference between type A and type B to occur. It is difficult to see how the absence of the indirect object could be related to Case reasons either. 
Why would inherent, lexically determined Case be absent in (16b), where it is present with the same adjectives (trouw, gehoorzaam) in (16a)? The difference between type A and type B thus appears to be determined by structural considerations.

\subsection{Prepositional objects}

A similar difference between type $\mathrm{A}$ - the subject is the possessor of the adjectival property and type B - the subject is the nominal phrase that expresses the adjectival property — we find with respect to the occurrence of prepositional complements. In the case of the adjectives trots 'proud' and nerveus 'nervous' the object can be expressed in a PP headed by the preposition op resp. voor, but only if the subject is the possessor. Again, there is no interpretive reason to expect the difference in grammaticality between $(17 \mathrm{a}, 18 \mathrm{a})$ and $(17 \mathrm{~b}, 18 \mathrm{~b})$ to occur.

(17) a Jan is trots (op zijn overwinning).

John is proud (of his victory).

b Jans houding is trots (*op zijn overwinning).

John's attitude is proud (*of his victory).

(18) a Jan is nerveus (voor het examen).

John is nervous (about the exam).

b Jans gedrag is nerveus (*voor het examen).

John's behaviour is nervous (*about the exam).

A difference which is similar to the difference between (17a, 18a) and (17b, 18b) has also been discussed by Higgins (1973) and Pesetsky (1995) for English adjectives. They observe that not all adjectives show this pattern, as is demonstrated in (19) and (20).

(19) a John is clear (to his students).

b John is reminiscent (of his father).

(20) a John's words are clear (to his students).

b John's behaviour is reminiscent (of his father).

The same is true for the Dutch equivalents of (19) and (20), as is shown in (21). 
(21) a Jan is duidelijk (voor zijn studenten).

John is clear (for his students)

b Jans houding is duidelijk (voor zijn studenten).

John's attitude is clear (for his students)

Crucially, the adjectives in (19)-(21) are ergative (cf. section 3). We thus may hypothesize that the non-occurrence of prepositional objects is restricted to unergative adjectives which do not have a possessor subject.

\subsection{Implicit arguments}

Another criterion that divides the class of unergative adjectives into two groups is the presence of an implicit argument. In the construction of type B - the construction which lacks a possessor subject — the possessor argument can be added in a PP headed by van 'of'. ${ }^{9}$ Of course this option is not available to the construction of type A, since a possessor is already present in the structure. This is shown in (22).

(22) a Jan is aardig / vervelend (*van Henk).

John is nice / annoying of Henk

b Dat is aardig / vervelend (van Henk). that is nice / annoying of Henk

\footnotetext{
9 The presentation simplifies the actual situation considerably (cf. Bennis 2000). The class of unergative adjectives can at least be separated into two different groups: adjectives denoting mental properties (cf. Stowell 1991) such as the ones discussed in the main text (e.g. aardig 'nice', trouw 'loyal'), and adjectives denoting psychological states such as moeilijk 'difficult' and interessant 'interesting'. In the B-type construction the latter group of adjectives selects a possessor (or experiencer) in a PP that is headed by voor 'for', instead of van 'of'.
}

(i) a Jan is moeilijk / interessant.

John is difficult / interesting

b Dat is moeilijk / interessant voor Jan.

that is difficult / interesting for John

I will leave this distinction within the class of unergative adjectives out of consideration here. 
If we take the van-phrase ('of') in (22b) to be parallel to the door-phrase ('by') in verbal constructions, the pair in (22) is reminiscent of the active / passive alternation. The external argument of the adjective in (22a) is realized in an optional PP in (22b). ${ }^{10}$ Thematically both the subject in (22a) and the object of the preposition van in (22b) refer to the possessor of the adjectival property.

An argument that corroborates a passive-like analysis along these lines is the fact that the possessor is implicitly present in (22b) when the optional van-PP happens to be absent. Just like in passive clauses, this implicit argument can be syntactically activated in controlling the subject of infinitives. This is shown in (23) and (25).

(23) a Het is aardig (van Jan) om PRO iets tegen mij te zeggen. it is nice of John for PRO something to me to say

b Het is vervelend (van Jan) om PRO dat aan mij over te laten. it is annoying of John for PRO that to me to leave

In (23) we find embedded subject clauses of the infinitival type. The relevant point here is that the PRO-subject of the infinitive is controlled by the possessor argument of the adjective. Even when no lexical possessor is available the sentence has to be understood in such a way that the person who is interpreted as the subject of the infinitival clause possesses the relevant adjectival property. This can be made explicit by replacing the adjectives in (23) by adjectives that do not have an implicit possessor, such as the ergative adjectives discussed in section 3. The ungrammaticality of (24a) and the contrast between (24a) and (24b) are easily explained if we assume that in this kind of infinitivals PRO should be controlled. The lack of an implicit possessor argument forces the subject clause to be finite.

(24) a *Het is duidelijk / waarschijnlijk om PRO iets tegen mij te zeggen.

it is clear / probable for PRO something to me to say

10 The fact that a sentence such as *Jan is dat aardig / vervelend is ungrammatical, is not due to thematic considerations, but rather to the fact that no structural accusative is available for the thematic object of the adjective. 
b Het is duidelijk / waarschijnlijk dat hij iets tegen mij zal zeggen.

it is clear / probable that he that he something to me will say

A similar argument can be made with respect to the much debated 'easy-to-please' construction in $(25)$.

(25) a Dat is aardig (van Jan) om PRO $e$ tegen mij te zeggen.

that is nice (of John) for PRO $e$ to me to say

b Dat is vervelend (van Jan) om PRO $e$ aan mij over te laten.

that is annoying of John for PRO $e$ to meto leave

I take the 'easy-to-please'-construction of the type in (25) to be the result of $w h$-movement of an empty operator to the [Spec,C] of the infinitival clause. This empty operator is coindexed with the matrix subject (dat in (25)). The relevant point here is the fact that PRO in the subject position of the infinitival clause is controlled by the implicit argument of the adjective. Even if the van-phrase is lacking the sentence has to be interpreted in such a way that the PRO-subject of the infinitival clause is identified as the implicit possessor of the adjectival property.

\subsection{An analysis of type $B$}

Let us try to make sense of the differences between type A and type B unergative adjectives in a structural way. A list of the differences between these two constructions is provided below.

\begin{tabular}{||lcc||}
\hline thematic interpretation of subject & type $A$ & type $B$ \\
occurrence of indirect object & possessor & theme \\
occurrence of PP-object & yes & no \\
implicit possessor & yes & no \\
van-PP & no & yes \\
\hline
\end{tabular}

The thematic organization appears to indicate that the relation between type A and type B is parallel to the relation between active verbs and passive verbs. Let us assume this to be the case. 
Until now I haven't said anything about passives. However, the line of argumentation in this paper forces us to take a particular stand on this issue. I argued above that in verbal constructions the presence of an agent or agentivity is determined by the presence of small $v$. Given that passives - in contrast to ergative verbal constructions - show agentivity and given that they arguably contain an implicit agent, passive structures have to be $v \mathrm{P}$. In the spirit of various proposals in the literature, we may argue that passive morphology is generated in $v$. The passive morpheme is then taken to host the implicit external agent (cf. Jaeggli 1986, Baker, Johnson \& Roberts 1989). The difference between passive and ergative structures can thus be traced to the presence or absence of small $v$. The similarity between the two resides in the fact that the theme argument shows up as the surface subject. In order to account for this we seem to be forced to assume that the Burzio generalization is reinvoked at the $v$-level: if $v$ does not assign a thematic role to the inner spec position, it does not assign structural objective Case to the outer spec position either. However, if we integrate the passive analysis of Baker, Johnson \& Roberts (1989) into our account, the correlation between the absence of an explicit agent and the unavailability of Case can be made to follow. Baker et al. argue that the implicit argument (or rather the passive -en morpheme) should receive Case. If that is correct, we may assume that the passive morpheme in $v$ checks its objective Case. ${ }^{11}$ In this way objective Case can no longer be checked by an object DP in the outer Spec of $v$. The passive part of the Burzio generalization can thus be made to follow from an analysis that is basically similar to the analysis given by Baker, Johnson \& Roberts (1989).

We now have identified two verbal constructions in which the absence of an external argument (inner spec of $v$ ) prevents the assignment of objective Case (outer $\operatorname{spec}$ of $v$ ). This leads to the configurations in (26) for resp. passive and ergative verbal projections.

11 The minimalist theory has identified two structural configurations in which formal relations can be established. In addition to the Head-Spec configuration discussed above, checking also takes place if two elements cooccur in a head position. The head-head configuration is the one relevant here. The passive morpheme in $v$ is able to check its Case feature with the Case feature in $v$. 
(26) a passive

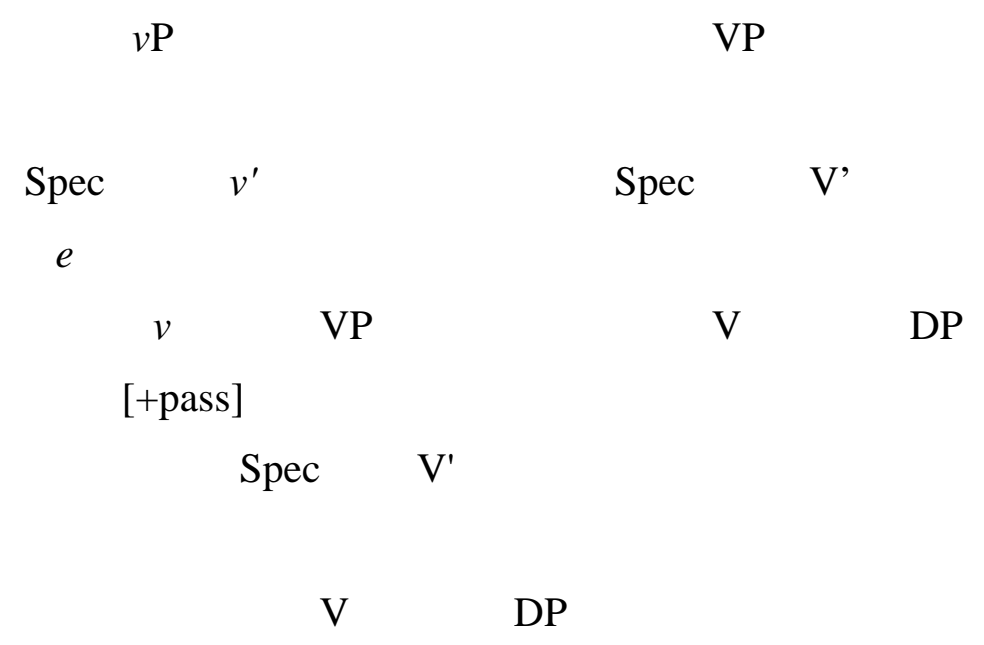

Coming back to the adjectival constructions under consideration here, we can express the difference between type $\mathrm{A}$ and type $\mathrm{B}$ unergative adjectives in a straightforward way. The structural difference between type A and type B concerns the availability of an external argument in the specifier position of the $a \mathrm{P}$. Just as in the verbal domain there are two different types of ergativity in the adjectival domain. Simplex ergativity in the case of adjectives such as duidelijk 'clear' and bekend 'well-known' (27b), and complex ergativity in the case of unergative adjectives that have been stripped of their external argument (27a).

(27) a complex ergative (cf.22b)

$a \mathrm{P}$

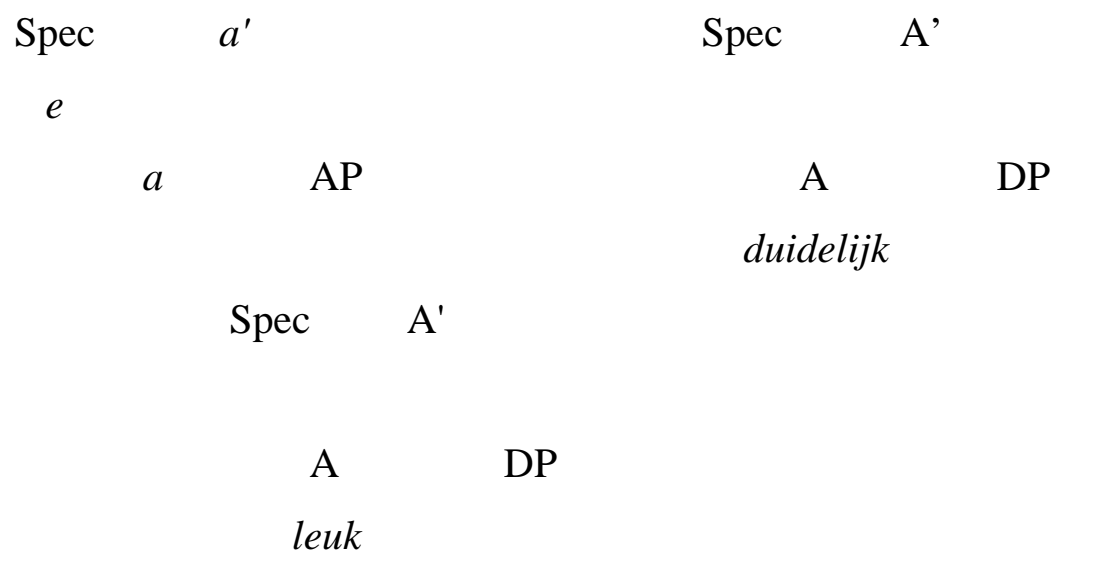

b simplex ergative (cf.4a)

AP

(a)

leuk 
In both cases the DP - the theme which expresses the adjectival property - has to be moved to a position in which it can check its Case feature. No structural Case is available within the projections (27a) and (27b). The DP thus has to move to the external subject position [Spec,T] in order to reach a position in which the Case feature might be checked. ${ }^{12}$

Although the thematic organization, the presence of an implicit argument, and the optional presence of a van-phrase in type B follow from this passive-like analysis, it does not yet explain why indirect objects and prepositional objects do not occur in type B constructions. This question appears to be complicated by the fact that indirect objects and prepositional objects do occur in configurationally similar passive constructions, as in (28).

Dat boek werd mij overhandigd.

that book was me given

b Dat werd tegen mij gezegd.

that was to me said

Similarly, as we have seen in section 3, simplex ergative adjectives may occur in combination with indirect objects. I will argue that the answer to this apparent puzzle lies in (relativized) minimality. Let us assume that movement of an object always targets the outer spec position of the $\mathrm{X} / \mathrm{x}$-projection. ${ }^{13}$ In simplex ergatives the target position is [Spec, $\left.\mathrm{V}\right]$ or $[\mathrm{Spec}, \mathrm{A}]$; in complex ergatives and unergatives, the target position is $[\mathrm{Spec}, v]$ or $[\mathrm{Spec}, a]$. It now follows that in ergative constructions object movement is not obstructed by minimality or locality considerations, since the adjoined object will always be the local binder of its trace. The presence

12 Of course the landing site of the DP that is on the run to find a Case checking environment may also involve the specifier position of $v \mathrm{P}$ in the case of small clause complements. This is what appears to happen in sentences such as in (i).

(i) Ik vind dat leuk/duidelijk. I find that nice/clear

13 This would follow if adjunction is restricted to minimal (heads) and maximal projections only. If VP/AP is taken to be a segment of $v \mathrm{P} / a \mathrm{P}$, object movement in non-ergative configurations should target $v \mathrm{P} / a \mathrm{P}$ directly. For discussion of this issue, see Chomsky (1995, ch.4). 
of an indirect object in [Spec,V/A] makes no difference since both specifiers are equidistant with respect to the object position. We thus expect ergative constructions to be able to appear with indirect objects. The situation differs if it concerns movement from the VP/AP-domain to the specifier position of $v \mathrm{P} / a \mathrm{P}$. In verbal constructions it has been argued (cf. Chomsky 1995) that movement from VP is contingent on head-movement of V. We may take movement to small $v$ to be a first step in the journey from $\mathrm{V}$ to $\mathrm{T}$. If we assume that in verbal constructions the verbal domain is enlarged by movement of $\mathrm{V}$ to $v$, the presence of an indirect object in [Spec, $\mathrm{V}]$ has no effect whatsoever on the movement of the object to [Spec,v]. No minimality problem arises. We thus expect objects to target [Spec,v], independent of the presence of another DP in [Spec,V] (the indirect object) or/and [Spec, $v$ ] (the external argument). In adjectival constructions of the type $a \mathrm{P}$ the situation is different. There is no obvious reason to assume that $\mathrm{A}$ has to move to the functional domain. If there is no head movement, movement of the object out of AP may give rise to minimality violations. This situation occurs if $[\mathrm{Spec}, \mathrm{A}]$ is filled with an argument. By moving the object to [Spec, $a$ ] the intervening argument in $[\mathrm{Spec}, \mathrm{A}]$ is closer to the trace of the object than the moved object in [Spec, $a$ ], thus ensuing a violation of the Minimal Link Condition (Chomsky 1995). ${ }^{14}$

We thus are able to explain the fact that internal arguments do not show up in adjectival constructions of type B. The at first sight surprising asymmetry between complex ergative adjectives and simplex ergative adjectives, and between complex ergative adjectives and complex ergative verbs (passives), now follows from locality considerations. ${ }^{15}$ This corroborates the distinction between simplex and complex ergative constructions.

Let us summarize the major results of this discussion of adjectival constructions:

- $\quad$ simplex ergative, adjectival constructions (adjectives such as duidelijk 'clear') are bare APs;

- $\quad$ other adjectival constructions have an $a$-shell on top of AP;

14 A crucial aspect in this analysis is that there is no movement from A to $a$. This might be problematic in that attributive adjectives show some inflection in Dutch. Another problem concerns the possibility of A-to-Q raising, as proposed in Corver 1997. I will have to assume that no movement is involved in these cases. I will leave this problem for further research.

15 This is also true for the English contrast given in (17)-(20), which has been discussed by Higgins (1973) and Pesetsky (1995). 
- $\quad a \mathrm{P}$ might be ergative (complex ergatives) or unergative;

- due to minimality, indirect objects and prepositional objects are barred from complex ergative, adjectival constructions.

- passive verbal constructions are structurally similar to complex ergative, adjectival constructions;

- $\quad$ ergative verbal constructions pattern with simplex ergative, adjectival constructions.

It is clear that until now notion of ergativity has largely been separated from the issue of Case checking. The distinction ergative - unergative has been argued to be relevant in contexts in which Case is irrelevant, as in adjectival phrases where no structural Case is available in general. In the following sections I will return to verbal constructions to see to what extent ergativity and Case are interrelated.

\section{Present Participles}

An interesting bridge between adjectival and verbal constructions is presented by the issue of present participles (cf. Bennis \& Wehrmann 1990). At least in Dutch, present participles appear to be exclusively adjectival in their distribution. They occur in attributive position within DP (29a), they appear in adjunct position within the middle field (29b), and some of them show up in predicative position, such as the copula construction in (30a) and the small clause construction in (30b). These positions are generally unavailable for verbal projections.

(29) a een ontroerende / pratende machine a touching / talking machine

b De machine stond ontroerend / pratend op mijn bureau. the machine stood touching / talking on my desk

(30) a Die machine is ontroerend / * pratend. that machine is touching / talking

b Ik vind die machine ontroerend / *pratend. I find that machine touching / talking 
Although externally adjectival, there are convincing arguments to claim that the internal make-up of present participle phrases (PPPs) can be verbal. The PPP may contain direct objects with structural Case and small clause complements. These possibilities point at a regular verbal construction, since direct objects and small clauses are not found within the class of 'real' adjectives. Some examples are given in (31) and (32).

(31) a een [mij veel overlast bezorgende] machine a [me IO $_{\text {IO }}$ much trouble $e_{\text {DO }}$ causing] machine

b De machine stond [mij veel overlast bezorgend] op mijn bureau. the machine stood $\left[\mathrm{me}_{\mathrm{IO}}\right.$ much trouble $\mathrm{DO}_{\mathrm{DO}}$ causing] on my desk de [[mij gelukkig] makende] machine the [[me happy $]_{\mathrm{SC}}$ making] machine

b De machine stond [[mij gelukkig] makend] op mijn bureau. the machine stood [[me happy]sc making] on my desk

In the domain of PPPs there is a very clear distinction between present participles of dynamic verbs, and present participles of stative verbs. PPPs with dynamic verbs only occur in attributive and adjunct position, as in (29), (31) and (32), but not in a predicative position, as in (30). This is not the case for stative verbs, among which the object experiencer verbs are most prominent. PPPs of these verbs show up in predicative position as well, as in (30). Interestingly, the internally verbal status of these stative PPPs is much less clear. This is especially true for stative PPPs in predicative position. I'll provide three arguments to show that stative PPPs might be analysed as adjectival internally: adjectival stress, intensification, and prefixation.

In Dutch particle verbs have stress on the particle. This is true both for dynamic and stative particle verbs. Dynamic PPPs show this stress pattern too. However, as soon as we find stative PPPs in predicative position, stress shifts to the verbal part of the present participle, corresponding to the pattern of complex adjectives. This is demonstrated in (33).

Jan zal mij uít-zwaaien / *uit-zwaáien.

[+dyn]

John will me out-wave 
b

Die baan zal mij uít-putten / *uit-pútten.

$[+$ stat $]$

that job will me ex-haust

c het mij uít-zwaaiende / *uit-zwaáiende publiek [+dyn PPP]

the me out-waving audience

d Die baan is *uít-puttend / uit-púttend.

$[+$ stat PPP $]$

that job is ex-hausting

In contrast to $(33 \mathrm{a}-\mathrm{c})$ the PPP in (33d) appears to be adjectival internally. The same point can be made with respect to intensification (cf. Brekke 1988, Borer 1990 for English). ${ }^{16}$ In Dutch there are various intensifiers. The interesting point is that heel 'very' can only be added to adjectival projections, whereas erg 'very' is possible both in verbal and adjectival contexts. The contrast between (34a) and (34b) follows if we take the PPP verrassend to be adjectival.

Zijn optreden is erg / heel verrassend.

his performance is very surprising

b Hij verrast mij erg / *heel.

he surprises me very

(35) a

een $\mathrm{erg} /$ *heel snurkende man

a very snoring man

b Deze man snurkt erg / *heel.

this man snores very

16

Brekke (1988) explicitly argues that only PPPs of experiencer verbs are internally adjectival, whereas other PPPs are verbal internally. This appears to be similar to the situation in Dutch, although the evidence in favour of a categorial distinction in English is much weaker than the evidence that is available for Dutch. The major argument produced by Brekke is the fact that intensification by very separates PPPs of experiencer verbs ("very interesting") from PPPs of other verbs ("*very jumping"). If it is correct that intensification by very is a test for true adjectival status, only PPPs of experiencer verbs qualify as adjectival projections. Borer argues against the qualifying status of very intensification. She concludes that all PPPs are adjectival. For Dutch the evidence that at least dynamic PPPs are internally verbal is overwhelming, as we have seen above. The fact that intensification in Dutch seems to pattern with English, thus appears to support the distinction that is defended in Brekke. 
It appears that no semantic or lexical restriction on intensification is relevant. The non-occurrence of heel in (35a) strongly suggests that dynamic PPPs are verbal, whereas the occurrence of heel in (34a) points at an adjectival internal structure.

A third argument for the dual nature of PPPs is the fact that adjectival affixation is possible with stative PPPs only, as is clear from on-prefixation and comparative formation.
a een on-opwindende man
(37) a
*een on-slapende man
an unexciting man
an unsleeping man
b een angstaanjagend-ere situatie
b *een werkend-ere student
a frightening-er situation
a working-er student

These three argument suffice to show that PPPs of dynamic verbs are internally verbal, whereas PPPs of stative verbs can be adjectival.

However, this qualification requires some further refinement. It seems to be the case that dynamic PPPs are always verbal, whereas the categorial make-up of stative PPPs is dependent on the structural position of the PPP. In adjunct position (attributive or adverbial) the stative PPP can be either adjectival or verbal, whereas an adjectival internal structure appears to be required for PPPs in complement position (predicative). This is demonstrated in (38) and (39).

(38) a de het antwoord wetende / alwetende geleerde the the answer knowing / all-knowing scientist

b Die geleerde is *het antwoord wetend / alwetend. that scientist is the answer knowing / all-knowing

(39) a het telkens weer ?ópwindende / opwíndende verhaal ${ }^{17}$ the again-and-again exciting story

b Dat verhaal is telkens weer *ópwindend / opwíndend. that story is again-and-again exciting

17 If both possibilities are available in principle, there exists a preference for adjectival stress. However, informants agree in that verbal stress is not impossible in these cases. The unacceptability of verbal stress in (39b-d) is clear and contrasts with the reduced acceptability of verbal stress in (39a). Similarly, the unacceptability of adjectival stress is absolute in $(40 \mathrm{a} / \mathrm{c})$. 
c het heel *ópwindende / opwíndende verhaal the very exciting story

d het *on-ópwindende / on-opwíndende verhaal the unexciting story

In (38) it is shown that stative PPPs may have direct objects in adjunct position only. In (39) we observe that stative PPPs may have verbal or adjectival stress in attributive position, whereas adjectival stress is required in the case of PPPs in complement position. Moreover, adjectival stress is required as soon as adjectival modification (intensification with heel or on-prefixation) shows up.

From this we conclude that the following empirical generalizations hold:

- PPP in adjunct position can be verbal;

- PPP can be adjectival iff $\mathrm{V}$ is stative;

- PPP must be adjectival if:

a. $\quad$ PPP is in complement position;

b. PPP shows adjectival modification (adj.morphology / intensification).

The relevant point to be made here concerns the appearance of the experiencer argument in the case of PPPs of psychological verbs. It appears to be the case that the experiencer may occur in PPP constructions only if the internal structure of the PPP is verbal. If the PPP is adjectival the object experiencer (OE) must be left out. This is demonstrated in (40).

(40) a de mij ópwindende gebeurtenis

the me exciting happening

b Die gebeurtenis is $(* \mathrm{mij})$ opwindend.

that happening is me exciting

c de $(*$ mij) opwíndende gebeurtenis

d de (*mij) heel opwindende gebeurtenis

the me very exciting happening

e de (*mij) onopwindende gebeurtenis

the me unexciting happening 
The particle verb op-winden 'to excite' is a psychological verb of the object experiencer (OE) type. In (40a) we observe that the OE (mij) may appear in a PPP construction. Above it was argued that PPPs of stative verbs in attributive position are structurally ambigious between an adjectival and a verbal internal structure. In (40b) it is demonstrated that the OE (mij) does not appear when the PPP is a predicate in complement position. The ungrammaticality of the OE in (40b) can be related to the categorial nature of the PPP. As demonstrated above, the PPP in complement position is adjectival. The conclusion that the presence of the object experiencer depends on a categorial distinction, is supported by the data in (40c)-(40e) as well. The OE (mij) becomes impossible in attributive position when the PPP has adjectival properties, such as adjectival stress (40c), intensification with heel (40d) or adjectival prefixation (40e). On the other hand, when the PPP is arguably verbal, as in (40a), the OE (mij) is possible. If we assume that the object experiencer must be Case-marked structurally, we can provide a simple explanation of the contrast between (40a) and (40b-e). Adjectival projections do not feature Case-checking heads; if the OE must be structurally Case-marked, we expect the $\mathrm{OE}$ to occur in verbal projections only.

We thus find ourselves in the position that we have strong arguments to claim that the presence of an object experiencer in PPPs is dependent on the presence of structural Case. At this point I disagree with an approach of the type adopted in Belletti \& Rizzi (1988) in which the object experiencer is assumed to have inherent Case. The correlation between the categorial status (verbal vs adjectival) and the appearance of an object experiencer cannot be explained easily if we assume the object experiencer to have inherent Case, since, as argued above (cf. (4)), inherent Case can be present both in verbal and adjectival constructions in Dutch.

In section 2 we have argued that structural objective Case depends on the presence of small v. Combining these results, we are now led to the conclusion that an object experiencer PPP may contain a $v \mathrm{P}$ and that the $\mathrm{OE}$ must be moved to the outer Spec position of this $v$ in order to check its objective Case feature.

The major result of this section is that the object experiencer of PPPs of psych verbs should receive structural objective Case. In the next sections regular OE-verbs will be discussed. The most important issue concerns the argument structure of psych verbs and the relationship between the presence of an external argument and the availability of objective Case. 


\section{Complex ergative verbs}

In the literature the argument structure of psychological verbs and the related projection of arguments into the syntactic structure has been the cause of much debate (cf. Belletti \& Rizzi 1988, Pesetsky 1995, Grimshaw 1990, Arad 1998 a.o.). Most authors agree that an unaccusative perspective on object experiencer verbs, as proposed by Belletti \& Rizzi, is incorrect (Pesetsky, Grimshaw, Arad). In this section I'll provide arguments to claim that psychological verbs are ergative, though not unaccusative. They are the verbal counterparts of the complex ergative adjectives, discussed in section 4 . The proposal defended here is in between the unaccusative analysis of Belletti \& Rizzi (1988) and the unergative analysis of the others.

Let us first compare standard psych verb constructions with their 'real' causative counterparts. In (41) a number of typical psych verb constructions are listed. The experiencer is present as an object, and the theme - the object which causes the emotion - appears as the subject. Related to these constructions are the examples in (42), in which the subject is the possessor of the object that causes the emotion (the Causer). In this case, the object that causes the emotion can be present in an optional PP.

$$
\begin{aligned}
& \text { Dat gedrag amuseert / ontroert / verbaast / interesseert / ... mij. } \\
& \text { that behaviour amuses / moves / astonishes / interests / ... me } \\
& \text { Jan amuseert / ontroert / verbaast / interesseert / ... mij met dat gedrag. } \\
& \text { John amuses / moves / astonishes / interests / ... me with that behaviour }
\end{aligned}
$$

The sentences in (42) appear to be normal transitive clauses with an external argument, generated/merged in $[\mathrm{Spec}, v]$. The experiencer is a direct object in all relevant respects. Two arguments in favour of the direct object status of the experiencer in (42) concern the availability of passive variants, and the occurrence in participle constructions. Passive variants of (42) are presented in (43).

(43) a Ik werd door Henk geïnteresseerd voor taalkunde.

I was by Henk interested for linguistics

b Ik werd door Jan ontroerd met een serenade.

I was by John moved with a serenade 
Given the analysis of passivization along the lines of Baker, Johnson \& Roberts (1989), as discussed above, it follows that the direct object cannot check its Case by movement to the outer Spec of $v$, given that the passive morpheme checks the objective Case feature in $v$. The object thus has to move to $[\mathrm{Spec}, \mathrm{T}]$ in order to pass the Case requirement for DPs. It thus follows that in causative constructions of the type in (42) the experiencer is structurally Case marked, either by adjoining to $v \mathrm{P}$ in active clauses (42), or by adjoining to TP in passives (43).

A similar argument can be derived from the distribution of past participles. If the participle of a verb is used in attributive position within DP, the head noun of the DP corresponds to the (underlying) direct object. This is demonstrated in (44) for a normal bitransitive verb. In (45), we observe that causative psych verbs behave similarly.

(44) a De jongen overhandigt de voorzitter een cadeau. the boy gives the chairman a present

b *de overhandigde jongen (the given boy)

c *de overhandigde voorzitter (the given chairman)

d het overhandigde cadeau (the given present)

(45) a De jongen amuseert het publiek met een redevoering. the boy amuses the audience with a speech

$\mathrm{b} \quad *$ de geamuseerde jongen $\quad$ (the amused boy) ${ }^{18}$

c het geamuseerde publiek (the amused audience)

d * de geamuseerde redevoering (the amused lecture)

If causative psych verb constructions of the type in (42) are regular transitive constructions indeed, it appears to be the case that the psych verb constructions in (41) are the ergative counterparts of these transitives. However, not in the normal sense of ergativization. The experiencer object of the unergative clauses in (42) still appears as the direct object of the ergative clauses in (41). What happens to become subject in the 'ergative' variant is the object

18 This phrase is ungrammatical in the intended interpretation in which de jongen 'the boy' is the causer of the emotion. 
that causes the emotion (the Theme); the phrase that shows up in a prepositional phrase in the non-ergative construction. There are at least four arguments to claim that (41) is ergative:

(i) an internal argument of the unergative construction shows up as the subject of the ergative construction (cf. (41) vs (42));

(ii) the external argument of the unergative construction can be added in an optional PP;

(iii) the two arguments of the ergative construction behave as internal arguments with respect to inversion (cf. 3.1);

(iv) the subject of the ergative construction behaves as an object with respect the occurrence in as-clauses (cf. 3.2).

The arguments (ii)-(iv) are illustrated below. As in the complex adjectival construction discussed in section 4, the external argument of the unergative construction can be added to the ergative construction in a van-phrase. Examples are provided in (46).

$$
\begin{aligned}
& \text { Dat verbaast / irriteert / ... mij van hem. } \\
& \text { that astonishes / irritates / ... me of him }
\end{aligned}
$$

In 3.1 is was shown that the inversion of arguments in Dutch is exclusively restricted to cases in which the surface subject is an underlying direct object. The fact that the construction in (41) readily allows this kind of inversion constitutes a strong argument in favour of a derivational approach. Instances of inversion are given in (47b).

(47) a dat die voorstelling mij amuseert / behaget / irriteert / ...
that that performance me amuses / pleases / irritates / ...
b dat mij die voorstelling amuseert / behaagt / irriteert / ...
that me that performance amuses / pleases / irritates / ...

A final argument concerns the appearance of psych verbs in as-clauses. In the examples in (48) the experiencer is lexically realized, and we encounter a gap in subject position. As has been argued above (cf. Stowell 1987), the gap in as-clauses corresponds to a sentential underlying object. If that is correct, it supports an ergative analysis of the construction in (41). 
(48) a Zoals mij telkens weer verbaast, houdt Jan van slakken.

as me again-and-again surprises, loves John snails

b Zoals mij altijd irriteert, wast Jan zijn handen niet voor het eten.

as me always irritates, washes John his hands not before dinner

The conclusion from this section thusfar is that the subject of an EO psych verb construction as (41) is derived by movement from object position. Apparently this contradicts the conclusion we have reached in the preceding section, where it was argued that the experiencer is assigned objective Case. If the subject of a psych construction of the type in (41) is an object, the construction does not have an external argument. If the Burzio generalization is correct, the lack of an external argument implies the absence of structural objective Case. Given that both structural claims - EO psych verbs have no EA and the EO receives structural, objective Case - have been empirically motivated rather extensively, we have to conclude that the Burzio generalization is empirically wrong.

Let us try to provide a structural analysis of EO psych verbs. Given that the EO bears structural objective Case, the verb phrase should contain a v-layer. Given that the EO construction should receive an ergative analysis, no external argument is generated in [Spec,v]. The two arguments in an EO construction should be analysed as internal arguments, i.e. arguments within VP. The question that remains is how these two arguments are projected: which of the two is generated in the specifier position of $\mathrm{V}$ and which one in complement position. There are various arguments suggesting that the experiencer is in $[\mathrm{Spec}, \mathrm{V}]$ and the Theme (the object that causes the emotion) in complement position. For instance, NP-inversion in Dutch shows up only if both orders are structurally motivated. In those cases in which the 'thematic order' differs from the 'Case order', as in passives of bitransitive verbs or ergative verbs with an indirect object, NP inversion can be observed. If that is the correct generalization, it follows that the occurrence of NP-inversion in EO constructions, as in (47), leads us to analyse the experiencer as being generated in $[\mathrm{Spec}, \mathrm{V}]$ : the order nominative-accusative $(47 \mathrm{a})$ is the order that corresponds to 'Case order', whereas the opposite order (47b) should correspond to the underlying order. Let us thus assume that EO is generated in $[\mathrm{Spec}, \mathrm{V}]$. This results in the underlying structure in (49). 


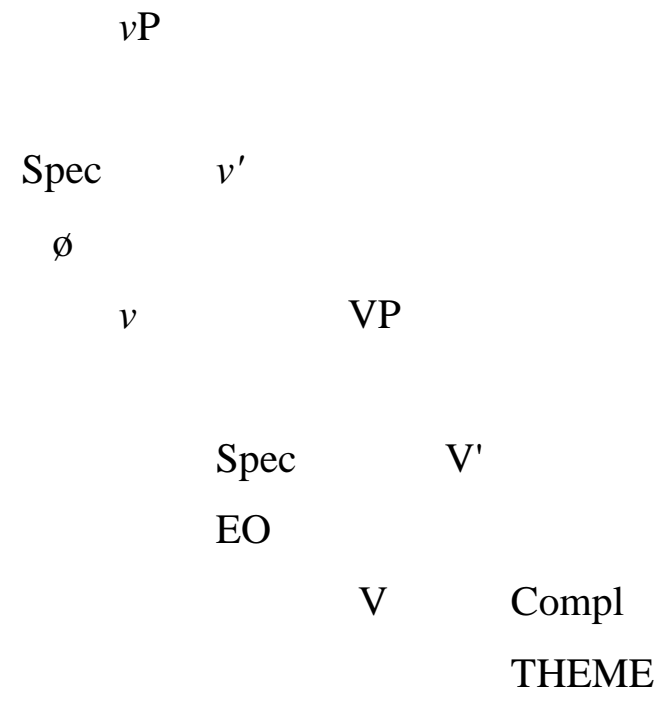

Both arguments in (49) have to be moved in order to check their Case features. Given the presence of $v$ - which automatically implies the interpretive aspect of Agentivity/ Causativity

- and the absence of a Case-absorbing passive morpheme, accusative Case is available. If it concerns a finite clause, nominative Case is available as well. EO will be adjoined to $v \mathrm{P}$ in order to check accusative Case. Given that $\mathrm{V}$ moves to $v$ and $v$ to $\mathrm{T}$, the Theme can be moved to [Spec,T] without violating locality or minimality constraints. The important point is that the exceptional behaviour of EO psych verb constructions can be accounted for without stipulation by introducing the concept of complex ergativity.

Before drawing a conclusion based on the distinction between simplex and complex ergativity, I will demonstrate how the variety of psych verb constructions can be accounted for in a framework as sketched above.

\section{$7 \quad$ Psych verbs}

In the literature a distinction has been made between three different types of psych verb constructions. The first distinction is whether the thematic experiencer shows up as the subject or the object of the construction. This difference is illustrated by the standard examples in (50). The relevant groups of psych verbs are also known as the temere (It. 'fear') class of psych verbs (subject experiencer) and the preoccupare (It. 'preoccupy') class (object experiencer). 
$\begin{aligned} & \text { (50) a John fears snakes. } \\ & \text { b } \text { Snakes frighten John. }\end{aligned}$

The second division is more subtle. The class of verbs with object experiencers is often divided into 'unergative' OE psych verbs (the preoccupare class; OE1) and 'ergative' OE psych verbs, the piacere (It. 'please') class of psychological verbs (OE2).

In this section I'll indicate how the three groups of psych verbs are structurally distinguished within the framework developed above. Let us first concentrate on subject experiencer verbs. As far as I can see, there is no reason to consider subject psych verbs to be a separate class of verbs. They belong to the class of stative verbs with an external argument (i.e. $v \mathrm{P}$, where $v$ is [+stat] (cf. $\S 2)$ ). The similarity between the two can be illustrated by the possibility to change these verbal constructions into possessive constructions which are construed by using the possessive verb hebben 'to have' and changing the verb into a bare nominal, as in (52).

(51) a Jan kent mijn antwoord.

John knows my answer

b Jan vreest / bewondert / waardeert mijn antwoord.

John fears / admires / appreciates my answer

(52) a Jan heeft kennis van mijn antwoord.

John has knowledge of my answer

b Jan heeft vrees / bewondering / waardering voor mijn antwoord.

John has fear / admiration / appreciation for my answer

Subject experiencer verb construction are regular transitive constructions in which the head of the $v$-layer is interpreted as stative. There appears to be no structural difference between the constructions which are traditionally labelled as being 'stative' and those which are called 'subject experiencer verb constructions'.19

19 One major difference between 'know' and 'fear' is the fact that passivization is easily available for verbs of the subject experiencer type, whereas it appears to be impossible for 'know'. Structurally, the occurrence of 
More interesting is the group of object experiencer verbs. In $\S 6$ the case of complex ergative psych verbs was discussed at some length. The question now arises how we can account for the distinction between the two groups of object experiencer verbs (OE1 vs OE2). Before jumping to the rather obvious conclusion, I will first illustrate that a division into two groups of object experiencer verbs is indeed motivated in Dutch on empirical grounds. There are at least four criteria to substantiate this division:

(i) auxiliary selection;

(ii) passivization;

(iii) past participle constructions;

(iv) present participles constructions.

Well-known is the fact that OE-verbs fall in two groups with respect to the selection of the auxiliary. In general, ergative verbs select the auxiliary zijn 'to be', whereas unergative verbs select the auxiliary hebben 'to have' (cf. Hoekstra 1999). Some OE-verbs (OE2) select zijn (53a), others (OE1) select hebben (53b).

(53) a Dat is mij bevallen / tegengevallen / overkomen. that is me pleased / disappointed / happened

b Dat heeft mij geamuseerd / geirriteerd / opgewonden. that has me amused / irritated / excited

This indicates that OE2-verbs such as bevallen are ergative, contrary to the OE1-verbs that have been discussed in $\$ 6$.

OE2-constructions (53b) have passive variants, whereas no passives are available for OE1-verbs of the type bevallen. ${ }^{20}$ This is shown in (54).

passivization is expected, since these verbs are regular unergative verbs. The ungrammaticality of passivization in the case of 'know'-verbs remains to be explained.

20 It appears to be the case that the participle in (54b) is adjectival: the passive auxiliary worden 'become' can be replaced by the verb raken 'get' and the participle allows adjectival modification with heel (cf. section 5). However, it does not seem to diminish the relevance of the contrast in (54). 
(54) a *Ik word daardoor bevallen / overkomen.

I am thereby pleased / happened

b Ik word daardoor opgewonden / geirriteerd.

I am thereby excited / irritated

A third difference between the two classes of OE-verbs concerns the behaviour of past participles in attributive position. Whereas the head of the relevant DP corresponds to the object of OE1-verbs (56), it corresponds to the subject of OE2-verbs (55). ${ }^{21}$

(55) a Dat gedrag bevalt de directeur.

that behaviour pleases the director

b het bevallen gedrag

the pleased behaviour

c $\quad *$ de bevallen directeur

the pleased director

(56) a Dat gedrag windt de directeur op.

that behaviour excites the director

b *het opgewonden gedrag c de opgewonden directeur the excited behaviour the excited director

Finally, the two classes of $\mathrm{OE}$-verbs behave differently with respect to their occurrence as present participles. Whereas OE1-verbs are ambiguous between an adjectival and a verbal internal structure, as has been discussed in $\$ 5$, no such ambiguity arises with OE2-verbs of the type bevallen. These latter verbs are exclusively verbal internally, similar to non-stative verbs. The non-occurrence of OE2-verbs with adjectival intensification (57a) and in complement position (58a) contrasts with the behaviour of OE1-verbs. ${ }^{22}$

21 The ungrammaticality of (55c) and (56b) concerns the intended interpretation only. (55c) can be interpreted in such a way that the director is the theme argument, and not the experiencer.

22 The verb opvallen 'to strike' does not behave as expected. It is one of the OE2-verbs with respect to auxiliary selection (zijn 'to be'), absence of passivization and past participle behaviour. However, with respect to present participles it behaves like OE1-verbs: it allows adjectival modification, adjectival prefixation, adjectival stress, and it occurs in complement position. I have no idea why this verb shows this atypical behaviour. 

(57) a
een $*$ heel / erg tegenvallende voorstelling a very / very disappointing performance
b een heel / erg opwindende voorstelling a very / very exciting performance
*Die voorstelling is bevallend. that performance is pleasing
b Die voorstelling is opwindend. that performance is exciting

Having established that a distinction between OE1-verbs and OE2-verbs is motivated, the question arises as to how this distinction can be accounted for structurally. As indicated above, the solution is quite obvious. OE1-verbs are the complex ergative verbs discussed in $\S 6$ above. This allows us to analyse OE2-verbs as simplex ergative verbs. Let us investigate how the differences between OE1 and OE2-verbs may follow from a structural difference in terms of simplex vs. complex ergativity. The selection of the auxiliary (hebben vs zijn) has always been a theoretical problem. It provided a test to distinguish ergative from unergative verbs, but is was unclear how it should be accounted for. On the basis of the discussion here, we may formulate a provisional analysis: hebben is selected if the complement is $v \mathrm{P}$, otherwise the auxiliary is zijn. ${ }^{23}$

The occurrence of passives was argued to be dependent on the presence of the $v$-layer (§4.4). Given that the $v$-layer is absent in simplex ergatives, no passivization of OE2-verbs is expected. The difference with respect to past participle interpretation may follow as well. In OE2-verbs, the experiencer is an indirect object with inherent Case. Given that the head noun in an attributive participle projection corresponds to the underlying direct object, it is to be expected that the head noun corresponds to the surface subject in simplex ergative OE2-constructions. For OE1-constructions the matter is more complicated. In these complex ergatives both DPs may considered to be direct objects: the theme is a direct object thematically, whereas the experiencer

23 The problem with such a formulation of auxiliary selection is the fact that the auxiliary is zijn in the case of passives. In $\$ 4.4$ it was argued that passives are $\nu$ Ps. It might be possible to maintain the proposed aux-selection procedure if we analyse passive participles as adjectival externally (i.e. $a \mathrm{P}$ ). This would also provide an answer to the question why passive participles appear in attributive position, contrary to active participles. For reasons of 
is a direct object with respect to Case. Apparently, structural accusative Case is the relevant criterion in selecting the argument that is targeted in participle constructions. This fits in with the general approach to this phenomenon in which it is assumed that attributive participles are passive participles. Finally, the difference in behaviour with respect to present participle formation may also be related to the structural difference between simplex and complex ergativity. The crucial point being that the lack of a $v$-layer in simplex ergatives makes it impossible to initiate a categorial change from $v$ to $a$. Such a categorial change is only possible if $v$ is stative just like adjectives. The fact that only unergative stative verbs and complex ergative verbs allow such a categorial transformation, supports the theory as developed above.

We thus conclude that the set of psychological verbs can be divided into unergative stative verbs (subject experiencer verbs), complex ergative verbs (OE1-verbs) and simplex ergative verbs (OE2-verbs). There appears to be no clear reason to argue that psychological verbs are to be distinguished theoretically. It is also unclear whether the notion 'experiencer' has any theoretical significance. What has to distinguished in the lexicon is whether a particular verb has a $v$-layer or not. Preferably this distinction is related to an aspectual distinction. A second division concerns the question whether a particular $v$-projecting verb may occur without external argument (unergatives vs complex ergatives). Again it might be the case that the availability of this option is semantically determined. The fact that typically psychological verbs (OE1) appear as complex ergatives might be the result of the absence of the external argument. In that case the meaning of the OE1 construction might be the consequence of the absence of the external argument, combined with the presence of the causativity in $v$.

\section{Conclusion}

Just as in adjectival constructions, it appears to be the case that the concept of verbal ergativity is not monolithic structurally. Actually we have encountered three different configurations in which the external argument is absent:

a) there is no $v$-layer on top of VP

consequences: no external argument, no accusative Case;

space, I will not elaborate on this issue here. Another way to approach this issue is to claim that hebben is selected if the $v$ is able to assign Case to [Spec,v]. If not, i.e. in the case of simplex ergatives and passives, the auxiliary is zijn. 
b) there is a $v$-layer on top of $\mathrm{VP}$, and $v$ contains a passive morpheme consequences: the passive morpheme absorbs the external argument and accusative Case;

c) there is a $v$-layer on top of VP and no external argument is generated; consequences: accusative Case is available.

These three configurations correspond to (simplex) ergative constructions, passive constructions, and experiencer object constructions respectively.

Theoretically it does not require much to obtain this three-way distinction. The theoretical assumptions that are required to reach this attractive result are:

- $\quad$ the verb phrase is/can be a layered constituent;

- the external argument is the specifier of $v$;

- $\quad$ structural accusative Case is checked in $v \mathrm{P}$;

- $\quad$ the passive morpheme is generated in $v$; it absorbs the thematic role and the Case features of $v$;

- $\quad v$ may or may not have a phrase generated in its specifier position.

With respect to the concept of 'unaccusativity' I conclude that this concept lacks any theoretical relevance. The availability of accusative Case is an automatic consequence of the presence of $v$. The accusative Case feature can be checked in the outer Spec position of $v$ (structural accusative Case) or in the head position (passive morpheme). Absence of the $v$-layer implies the absence of accusative Case.

The concept of 'ergativity' is not a primitive of the theory either. It is interpreted as the empirical correlate of structures in which no external argument has been generated. This can be due to the lexically/semantically determined absence of the $v$-layer ('simplex ergativity') or to the absence of an argument in the specifier position of $v$ ('complex ergativity').

The theoretical axiom that is known as 'the Burzio generalization' is now deprived of any theoretical significance as well. It is indeed true that the presence of an external argument correlates with the availability of accusative Case. If an external argument is present, it indicates the presence of a top-layer or an $x$-layer; if this layer happens to be of the type $v \mathrm{P}$, accusative Case is available. However, it is not the case that the availability of accusative Case is indicative for the presence of an external argument. We have seen that EO psych verb constructions are a case in point: accusative Case is available although an external argument is absent. As claimed in 
section 2: the Burzio generalization is partially wrong, and in as far it is correct, it follows from the theory without additional stipulations.

Finally, the approach to unaccusativity adopted here makes no use of the semantic concept of telicity, as many others have proposed. I have defended a purely syntactic analysis of unaccusativity which does not directly involve the syntax-semantics interface. Empirically, this analysis is strongly supported by the occurrence of stative unaccusatives. If object experiencer verbs are ergative verbs indeed, the semantic approach that makes use of concepts such as telicity and agentivity is seriously weakened.

\section{Bibliography}

Alexiadou \& Anagnostopoulou (this volume) 'Voice Morphology in the Causative-Inchoative Alternation: evidence for a non-unified structural analysis of unaccusatives'.

Arad, M. (1998) VP-structure and the Syntax-Lexicon Interface. PhD diss. UC London.

Baker, M., K.Johnson \& I. Roberts (1989) 'Passive Arguments Raised'. Linguistic Inquiry 20:2. 219-251.

Belletti, A. \& L. Rizzi (1988) 'Psych-verbs and_theory'.Natural Language and Linguistic Theory 6. 291-352.

Bennis, H. (1986) Gaps and Dummies. Dordrecht: Foris Publications.

Bennis, H. (2000) 'Adjectives and Argument Structure'. In P. Coopmans, M. Everaert, J. Grimshaw (eds) Lexical Specification and Lexical Insertion. Amsterdam / Philadelphia: John Benjamins. 27-69.

Bennis, H. \& P. Wehrmann (1990) 'On the categorial status of Present Participles'. In R. Bok Bennema \& P. Coopmans (eds) Linguistics in the Netherlands 1990.Dordrecht: Foris Publications. 1-12.

Besten, H. den (1982) 'Some remarks on the ergative hypothesis'. Groninger Arbeiten zur Germanistischen Linguistik. 61-82.

Borer, H. (1990) 'V + ing: It walks like an adjective, It talks like an adjective'. Linguistic Inquiry 21. 95-103.

Borer, H. (this volume) 'The Grammar Machine'.

Brekke, M. (1988) 'The Experiencer Constraint'. Linguistic Inquiry 19. 169-180.

Burzio, L. (1986) Italian Syntax. Dordrecht: Reidel. 
Chomsky, N. (1995) The Minimalist Program. Cambridge (MA): The MIT Press.

Chomsky, N. (2001) 'Derivation by Phase'. In M. Kenstowicz (ed.) Ken Hale: A life in language. Cambridge MA: MIT-Press. 1-52.

Cinque, G. (1989) ‘On embedded Verb Second clauses and Ergativity in German'. In D. Jaspers et al. (eds) Sentential Complementation and the Lexicon. Dordrecht: Foris Publications. 77-96.

Cinque, G. (1990) 'Ergative Adjectives and the Lexicalist Hypothesis'. Natural Language and Linguistic Theory 8. 1-39.

Corver, N. (1997) 'The Internal Syntax of the Dutch Extended Adjectival Projection'. Natural Language and Linguistic Theory 15:2. 289-368.

Embick, D. (this volume) 'Unaccusativity as telicity checking'.

Everaert, M. (1982) 'A syntactic passive in Dutch'. Utrecht Working Papers in Linguistics 11. $37-73$.

Grimshaw, J. (1990) Argument Structure. Cambridge (MA): The MIT Press.

Hale, K. \& J. Keyser (1993) 'On argument structure and the lexical expression of syntactic relations'. In K. Hale \& J. Keyser (eds) The view from building 20. Cambridge (MA): The MIT Press. 53-109.

Higgins, R. (1973) The Pseudo-Cleft construction. Diss. MIT.

Hoekstra, T. (1984) Transitivity. Dordrecht: Foris Publications.

Hoekstra, T. (1999) ‘Auxiliary Selection in Dutch'. Natural Language and Linguistic Theory. 17:1. 67-84.

Hout, A. van (this volume) 'Acquiring unaccusativity: a cross-linguistic look'.

Jaeggli, O. (1986) 'Passive'. Linguistic Inquiry 17. 587-622.

Kratzer, A. (1994) The Event Argument and the Semantics of Voice. Ms. UMass. Amherst.

Kratzer, A. (1996) 'Severing the External Argument from its Verb'. In J. Rooryck \& L. Zaring (eds) Phrase Structure and the Lexicon. Dordrecht: Kluwer.

Landau, I. (2000) Elements of Control. Structure and Meaning in Infinitival Constructions. Dordrecht: Kluwer.

Larsson, R. (1988) 'On the double object construction'. Linguistic Inquiry 19. 335-391.

Pesetsky, D. (1995) Zero Syntax. Cambridge (MA): The MIT Press.

Reuland, E. (2000) Arguments and Case. Explaining Burzio's Generalization. Amsterdam / Philadelphia: John Benjamins. 
Stowell, T. (1987) ‘As So, Not So As'. ms UCLA.

Stowell, T. (1991) 'The alignment of arguments in Adjective Phrases'. Syntax and Semantics 25. 105-135. 